Boise State University

ScholarWorks

Political Science Faculty Publications and

Presentations

Department of Political Science

5-1-2010

Tax Increment Financing in Missouri: An Analysis of Determinants, Competitive Dynamics, Equity, and Path Dependency

Susan Mason

Boise State University

Kenneth P. Thomas

University of Missouri - St Louis

The final, definitive version of this paper has been published in the Economic Development Quarterly, Vol 24 (Iss 2), 2010. SAGE Publications, Inc., All rights reserved. DOI: 10.1177/0891242409358080 


\title{
TAX INCREMENT FINANCING in MISSOURI: An ANALYSIS of DETERMINANTS, COMPETITIVE DYNAMICS, EQUITY, and PATH DEPENDENCY
}

\author{
Susan Mason \\ Boise State University \\ Dept. of Public Policy and Administration \\ 1910 University Dr. \\ Boise Idaho 83725-1935 \\ United States \\ T: 208 426-2658 \\ F: 208 426-4370 \\ Kenneth P. Thomas \\ University of Missouri-St. Louis \\ Political Science \\ 1 University Blvd. \\ St. Louis, Missouri, 63121 \\ United States
}

Keywords: TIF, City Competition, Path Dependency and Missouri

Susan Mason is Assistant Professor in the Department s of Public Policy \& Administration and Political Science, Interim Director of the Master of Community and Regional Planning program and Director of Community and Regional Planning Graduate Certificate program at Boise State University. Her research areas include community and economic development and urban development and sustainability.

Kenneth P. Thomas is Associate Professor of Political Science and Fellow in the Center for International Studies, University of Missouri-St. Louis. His research specialty is investment incentives worldwide, and mechanisms for their control. He is currently completing a book manuscript, The Political Economy of Investment Incentives.

\begin{abstract}
:
Tax increment financing (TIF) has been a popular and controversial economic development tool for several decades. This research considers the determinants of competitive dynamics, equity, and path dependency on TIF use. We use logistic and ordinary least squares regressions on the approval, number, and value of TIFs in Missouri to flesh out the way the determinants contribute to TIF approval, value, and frequency of use. This study finds that there are competitive dynamics that affect TIF use: being adjacent to another city that uses TIFs increases the likelihood that a city will approve a TIF. The study finds evidence that TIF adoption patterns contribute to intermunicipal inequality, and provides some support for the importance of path dependency on TIF use.
\end{abstract}

Despite protracted debate, substantial disagreement persists regarding the use of state and local development incentives such as tax increment financing (TIF). Peters and Fisher (2004) argue that the case for incentives is unproven at best. Nevertheless, government officials continue to use them, which Schwartz, Pelzman, and Keren (2008) term "a riddle." U.S. state and local governments are estimated to spend about $\$ 50$ billion annually on development incentives (Peters \& Fisher, 2004; Thomas, 2000). If governments adopt TIF and other incentives because nearby jurisdictions do so ( $\mathrm{Li}, 2006)$, this could explain the disjuncture between theory and policy. Identifying the existence of competitive dynamics in the adoption of TIF, tax abatement, or other incentives can help us solve this conundrum. 
The patterns of incentive adoption may also run counter to the claimed purposes of incentive programs, such as reducing blight (Gordon, 2008). Recent evidence (Reese, 2006) has shown a continuing tendency for programs to exacerbate inequalities between municipalities, or at least not reduce them. One reason for this, Reese argues, is that a process of path dependency has taken place. Prosperous cities were the first to adopt such incentives, and familiarity with particular programs has led these cities to continue to adopt the programs more frequently over time compared to poorer municipalities. She showed that this process characterized Michigan's PA 198 tax abatement program and created a dynamic of worsening inequality. Using new data generated from the Missouri TIF program, we perform a preliminary analysis of determinants to understand more about competitive dynamics, equity, and path dependency. We find significant evidence of competitive dynamics, no positive and some evidence of negative equity effects, and results partially supportive of earlier findings regarding path dependency.

The article begins with a review of the literature on investment incentives generally and TIF in particular, with an emphasis on quantitative studies from the international to the local level. We then discuss the procedures and methods used in the study and present an analysis of the results. In the conclusion, we consider policy implications and directions for further research.

\section{LITERATURE REVIEW}

Man (2001) defines TIF as "a geographically targeted tax, expenditure, and regulatory inducement to a specific location" that works by using "taxes derived from the increases in assessed values (the tax increment) resulting from new development . . . to pay for infrastructure needs and development expenditures in the TIF district" (p. 1). This highlights the relevance of the wider literature on investment incentives to the discussion of TIF. Our discussion draws broadly on this literature and is grouped according to the three main themes of the article: competitive dynamics, equity, and path dependency.

\section{Capital Mobility and Competitive Dynamics}

The mobility of capital between jurisdictions underlies competition for investment among governments (Thomas, 2000). Research at the international level and within the United States finds evidence of the importance of capital mobility and the existence of competitive dynamics in the use of investment incentives. Aydin (2007) found for EU countries that the higher the ratio of mobile asset holders (such as manufacturing and finance) to immobile asset holders (such as mining, farming, nonfinancial services, and retail) within a country, the more state aid (i.e., subsidies) was given as a percentage of government revenue. Similarly, countries with a higher ratio of mobile to immobile asset holders provided a higher percentage of regional aid as a share of total state aid, implying that mobile asset holders were successful in extracting investment incentives because regional aid is the primary category used for investment incentives (see Wishlade, 2008). Moreover, Aydin found that for U.S. states, the higher the contribution of mobile asset holders to gross state product, the greater the number of types of incentive programs as measured in the Conway Data annual surveys. Li (2006) also found that developing countries adopt tax incentives when nearby countries do so. Studies of local TIF use have also found evidence of competitive dynamics among municipalities. Man (1999) found this in Indiana, with the adoption of TIF by neighboring cities increasing the likelihood of TIF adoption. Byrne (2005) found that TIF adoption by nearby suburbs increased a city's likelihood of adopting TIF in the Chicago metropolitan area. One issue that needs clarification is whether adjacency or distance is a better predictor of competitive dynamics.

\section{Equity}

One key issue in the policy evaluation of TIF or other investment incentives is whether they reduce existing inequalities between individuals and cities or in fact exacerbate them (Peters \& Fisher, 2004). Three variables can be considered here: poverty, per capita income, and unemployment. ${ }^{1}$ Prior research has not established a link between poverty rates and TIF or tax abatement adoption (Anderson \& Wassmer, 1995; Dye \& Merriman, 2000), suggesting that TIF has not helped reduce intermunicipal inequality in Michigan or Illinois, though neither has it exacerbated inequality. Reese (2006) found no link between a city's classification as "distressed" and its use of PA 198 abatements after controlling for past abatement use. On the other hand, Man (1999) found that cities with higher per capita income were less likely to use TIF, whereas Anderson and Wassmer found that cities with higher median household income had longer periods without using tax abatement than lower income cities did. The results for the 
effect of unemployment on investment incentives are more mixed. U.S. states with higher unemployment rates tend to have fewer types of subsidy programs, and European Union Member States also see a negative impact of unemployment on total state aid (Aydin, 2007). Other studies find no effect (Man, 1999).

\section{Path Dependency}

Reese (2006) argues strongly for the importance of path dependency in the use of tax abatements in Michigan. In her analysis, cities that used abatements early in the history of Michigan's PA 198 were likely to continue using them over time. Moreover, when she added this variable to what she calls "traditional" determinants, it greatly improved the explanatory power of the equations, whether the dependent variable was the number of abatements granted or the total value of the abatements. Her conclusion is that this pattern, one in which prosperous suburbs gave early and often, has caused the abatement process to exacerbate inequalities between municipalities, which is relevant to this study's concern with the existence of both path dependency and equity.

\section{Controls}

Though not the focus of this article, other potential determinants of TIF use that have been identified in other studies are also incorporated as control variables in our analysis. These include population and population growth (Anderson, 1990; Dye \& Merriman, 2000; Reese, 2006), percentage of owner-occupied housing (Byrne, 2005), government structure (Reese, 2006), having an economic development plan (Reese, 2006), and the use of other economic development tools (Man, 1999).

\section{RESEARCH DESIGN AND METHODOLOGY}

\section{Research Questions}

Three questions are addressed in this research:

1) Do cities use TIF to compete with other cities for investment? If so, then we would expect to find that being adjacent to a city using TIF will increase the likelihood of adoption of TIF, the likelihood of adoption of retail TIF, and the number and value of all TIFs and retail TIFs, while distance from the nearest city using TIF will decrease likelihood of adoption, number, and value.

2) Does the pattern of TIF usage in Missouri ameliorate or exacerbate inequality between municipalities? If the former is true, the poverty rate and unemployment rate should be positively related to the dependent variables, while median household income should be negatively related to them. The opposite results should occur if TIF usage is exacerbating inequality. There may, of course, be no effect.

3) Is TIF usage in Missouri path dependent? If so, we would expect to find that early adopters of TIF have awarded a greater number of TIFs and a larger amount of TIF funding.

\section{Research Design}

A mailing list of 236 cities in Missouri was assembled by combining a list provided by the Missouri Department of Economic Development with a published listing of contacts for all U.S. cities with populations above 2,500 (International City/County Management Association [ICMA], 2006). A survey (see Appendix A) was sent to the cities in the spring of 2008. Reminder postcards were mailed approximately three weeks later. A second mailing of the survey was sent to cities that had not responded, followed by telephone calls to city officials to conduct the survey by phone. The survey questions were modeled from surveys previously used by Reese (2001, 2006) in her research on Michigan tax abatements. Additional data on government structure were drawn from the ICMA 2006 Municipal Year Book. Data on population, income, owner-occupied housing, unemployment, and poverty were taken from the 2000 U.S. Census (U.S. Census Bureau, 2008). Data on the assessed value of property in each municipality in 1985 and 2005 (to obtain the change in values) were obtained from reports from the State Auditor of Missouri (1986, 2005). Early TIF adopters were identified through a compilation of individual projects reported in the annual reports on local TIF from the Missouri Department of Economic Development (2004, 2005). 


\section{Population}

Since the dynamics of core cities are different from their much smaller suburbs (Dye \& Merriman, 2000), St. Louis and Kansas City were not included. Cities with less than 2,500 in population were also not included in the model, resulting in a total of 185 cities for study, of which 171 (92\%) responded to the survey

\section{Measures}

Dependent Variables

Six models were run with different dependent variables. As seen in Table 2, each dependent variable was taken directly from the survey responses to the questions. The first dependent variable is a categorical variable indicating whether or not the city has ever approved a TIF. The second dependent variable is the number of TIFs adopted by the city. The third dependent variable is the value of all TIFs awarded by the city. The fourth dependent variable is whether or not the city approved a TIF for a primarily retail development. The fifth dependent variable is the number of retail TIFs adopted. The sixth dependent variable is the value of TIFs awarded for retail development.

\section{Independent Variables}

The independent variables related to competitive dynamics were constructed using geographic information system (GIS) software and data (Geolytics, Inc., 2000). The first is a dummy variable indicating whether or not the city is adjacent to another city that used TIF. The second is the distance to the nearest city that used TIF. The inequality variables (poverty rate, unemployment rate, and median household income) were taken from the 2000 U.S. Census. Early adoption was operationalized as having approved TIF before 1993, based on data from the Department of Economic Development's annual reports. The controls include three dummy variables, indicating council-manager government type (as opposed to mayor or commissioner), whether or not the city has an economic development plan, and whether or not the city uses other economic development tools. Interval level controls for population, population growth, and owner-occupied housing come from the 2000 U.S. Census, and the interval level control for average growth rates of assessed value of property from 1985-2005 come from the Missouri state auditor's office. Table 1 describes the variables in the model and Table 2 lists all the variables and their sources.

[Insert Table 1 and Table 2 about Here]

As seen in Table 3 the survey data reveal that $56 \%$ of cities used TIF and the average total amount awarded by cities was $\$ 12.7$ million. $^{2}$ The total amount of TIF awarded throughout Missouri by these cities was $\$ 1.7$ billion. Although not noted in the table, of the 204 TIFs awarded, 116 were reported as "primarily retail" and the total amount of TIF awarded that was primarily retail was $\$ 1.1$ billion. As noted in the table, the average retail TIF awarded was $\$ 7.7$ million. ${ }^{3}$ Forty-three percent of cities had a council-manager government. A majority of cities (74\%) reported having an economic development plan, with $52 \%$ of those indicating it is a formal and written plan. Sixty-seven percent of cities reported using other economic development tools. The most frequently reported tools were transportation development districts, community and neighborhood improvement districts, and empowerment zones. Additional economic and city demographic data for the cities are provided in the table. Table 3 reveals several statistically significant correlations but none that are likely to create multicollinearity problems in the analysis. Although there is a high correlation (-.739) between adjacency and distance to a city that uses TIF, these variables are never used in the same model.

[Insert Table 3 and Table 4 about Here]

\section{Methods}

Fourteen models were analyzed. Four binomial logistic regressions were estimated to assess the effect of the previously noted factors on the likelihood of a city (a) approving a TIF or (b) approving a TIF primarily for retail. Two regressions use adjacency to a city using TIF as the measure of competitive dynamics, while the other two use distance to the nearest city using TIF. The odds ratios in Table 5 indicate the likelihood of TIF approval for each variable that was statistically significant. An odds ratio greater than 1 indicates an increased likelihood that a oneunit change in the independent variable increases the odds of TIF approval by 1 minus the odds ratio figure. An odds 
ratio of less than 1 indicates a decrease in the odds for each one-unit change in the independent variable by 1 minus the odds ratio number. A negative sign before the odds ratio indicates that for an increase in the independent variable by one unit, the dependent variable would decrease by the odds ratio.

Ten ordinary least squares regression analyses are reported in Table 6. As in Table 5, the regressions are split up by the two alternative measures of competitive dynamics. The first four are on the dependent variable number of TIFs. Two of these regressions are reported using the variable early adopter, to test the effect of path dependency. Early adopter was only significant in these two equations, and hence the only time it is reported is in Table 6. Two regressions are reported for the dependent variable number of retail TIFs. Then four regressions, two each on value of all TIFs and value of retail TIFs, are reported.

\section{Findings}

The first logit model in Table 5 reveals that being a city adjacent to another city that has approved a TIF makes a city 1.63 times more likely to approve a TIF. Table 5 also reveals that for each $1 \%$ increase in the poverty rate the likelihood of approving a TIF decreases by $9 \%$. In addition, the first model shows that having an economic development plan and using other economic development tools both increase the likelihood of a city approving a TIF. Cities that have an economic development plan are nearly twice as likely to approve a TIF. Cities that use other economic development tools are 1.74 times more likely to approve a TIF project than cities that do not use other tools. In the second model in Table 5, including the variable that calculates the miles to the nearest city with a TIF shows that although this variable is not significant, taking this factor into account strengthens the decrease in likelihood of TIF adoption due to poverty, with a $1 \%$ increase in the poverty rate now causing an $11 \%$ decrease as opposed to $9 \%$ in the first equation. Unemployment is significant in this model: for every $1 \%$ increase in the unemployment rate, the odds of TIF approval go up by nearly $50 \%$. In this model, the effects of having an economic development plan and experience with other economic development tools are reduced compared with the first model. Additionally, this model reveals an effect for population: For every 1,000-person increase in the city's population the likelihood of TIF approval increases by $4 \%$.

Table 5 also reveals that not all the same factors are at work when considering approval of TIFs that primarily foster retail development. Being adjacent to a city that has approved a TIF increases makes a city almost twice as likely to approve a TIF for retail development. For every $1 \%$ increase in the unemployment rate the odds of TIF approval go up by nearly $65 \%$. The use of other economic development tools increases the likelihood of approving a TIF by more than three times. Additionally, for every 1,000-person increase in city population the likelihood of TIF approval increases by $3 \%$. When considering the model that includes miles to the nearest city that uses a TIF rather than adjacency to a TIF city, for every $1 \%$ increase in the poverty rate there is a decrease of $13 \%$ in the odds of a retail TIF being approved. The effect of unemployment and population are slightly stronger in terms of increasing the odds of TIF approval for retail development, while the use of other economic development tools has a slightly weaker impact than in the third equation.

\section{[Insert Table 5 about Here]}

As seen in the first two regression equations in Table 6, there is virtually no difference between the model with adjacency to a TIF city and the model with the variable for miles to the nearest city that approved a TIF. In both cases, only economic development plans and population are statistically significant in relation to increasing the number of TIFs approved. The one notable difference is that adjacency, but not miles, is statistically significant. Being adjacent to a city with a TIF increases the number of TIFs approved by 1.01 TIFs. Having an economic development plan increases the number of TIFs approved by 0.68 of a TIF, and a 1,000-person increase in population increases the number of TIFs approved by 0.03 of a TIF. The next two equations in Table 6 include the variable early adopter and its impact on increasing the number of TIFs approved. As can be seen, the inclusion of this variable substantially increases the adjusted $\mathrm{R}^{2}$, from .21 in Equation 1 to .37 in Equation 3 , and from .16 in Equation 2 to .33 in Equation 4. The effect of adjacency to a TIF city increases the number of TIFs approved by 0.82 of a TIF, while the effect of being an early adopter of TIF as an economic development tool increases the number of TIFs adopted by 3.62 TIFs in Equation 3. The impact is even greater in Equation 4, where being an early adopter increases the number of TIFs approved by 3.81 TIFs, although distance to the nearest TIF, unlike adjacency, is not significant. In both models, a population increase of 1,000 people increases the number of TIFs approved by 0.03 of a TIF, while the effect of having an economic development plan is no longer significant. In the next two models in 
Table 6, the only factor that is significant in both of the models predicting retail TIF use is population. For every 1,000-person increase in the population of a city the number of retail TIFs increases by 0.02 of a TIF. In the model with the variable adjacent to TIF city, adjacency predicts an increase in the number of retail TIFs by 0.56 of a TIF.

Table 6 reveals that across all models the only variable that consistently predicts the value of a TIF is population. The value of all TIFs increases by approximately $\$ 630,000$ for each 1,000-person increase in a city's population. In the models for the value of retail TIF a 1,000-person population increase in a city increases the value of the retail TIF by approximately $\$ 468,000$. In both models on retail TIFs, adjacency and miles to the nearest city with a TIF are not significant. However, the use of other economic development tools and the percent of owner-occupied housing are statistically significant in the retail TIF model. A city's use of other economic development tools increases the total value of retail TIF by approximately $\$ 8.85$ million. Additionally, for each percentage increase in a city's owner-occupied housing, the total value of retail TIF increases by approximately $\$ 360,000$. Across all the models, adjacency gives a better fit than distance, suggesting that adjacency is a better predictor than distance of competitive dynamics. Therefore, our preferred specifications are Equations 1 and 3 in Table 5, and Equations 1, 3, 5,7 , and 9 in Table 6.

\section{[Insert Table 6 about Here]}

\section{CONCLUSIONS}

In our preferred specifications the models show substantial evidence of competitive dynamics. The adoption of TIF by a neighboring municipality made a city more than two and half times as likely to adopt any TIF, and almost tripled its likelihood of adopting a retail TIF. This indicates that Missouri cities use TIF to compete with other cities for investment. Moreover, we found some evidence that TIF adoption patterns contribute to intermunicipal inequality. Cities in Missouri with higher poverty rates were less likely to adopt TIF than those with lower poverty rates, and median household income was never statistically significant. These outcomes indicate a failure of TIF to combat existing inequality. Evidence was mixed on whether cities with higher unemployment rates were more likely to adopt TIF. In our preferred specifications, unemployment was significant for adoption of retail TIF, but not for adoption of all TIFs or for the number or value of all TIFs and retail TIFs. Finally, we find some support for Reese (2006) on the importance of path dependency, as cities which were early adopters of TIF (1987-1992) adopted 3.62 more TIFs and 3.81 more retail TIFs, controlling for other factors. However, there was no evidence that early adopters made larger cumulative TIF awards than other cities.

Among the control variables, the most consistently significant independent variable was population, which was positive and significant in all but one of the preferred specifications. Other factors, such as having an economic development plan and experience with other economic development tools, not surprisingly were significant when it came to predicting TIF approval. Having an economic development plan also had a positive impact on the number of TIFs approved, but that effect dropped out after controlling for early adopters. A city's use of other economic development tools had a substantial impact on the value of retail TIFs in Missouri. Contrary to Byrne's findings, we find that owner-occupied housing is only significant in determining the value of retail TIFs. Government structure and change in total assessed value were not statistically significant in any of the models, the latter of which is contrary to Anderson's (1990) and Reese's (2006) findings.

\section{Policy Implications and Future Research}

The strong impact of adjacency on TIF adoption may help explain why so many jurisdictions adopt development incentives despite what Peters and Fisher (2004) describe as a lack of strong evidence for their efficacy and efficiency. As noted earlier, Man (1999), Byrne (2005), and Li (2006) all found evidence that governments reacted to the adoption of incentives by other jurisdictions. An even stronger finding would be that failure to use incentives causes the loss of investment, not merely that governments react to other governments' use of incentives (Guisinger, 1985). Some evidence for this exists both within the United States (Head, Ries, \& Swenson, 1999) and at the international level (Harding \& Javorcik, 2007). Additional research at the municipal level would increase our understanding of this issue. The policy implication of such a finding might be that it would be desirable for governments to cooperate to reduce their use of incentives to increase efficiency and equity. This type of coordination has been implemented, for example, by the European Union (Albornoz \& Corcos, 2007; Barros \& Cabral, 2000). 
By partly supporting Reese's (2006) finding of the importance of path dependency, this work strengthens the case for better targeting of incentives. As Reese argues, the combination of untargeted incentives and path dependency is a recipe for incentive programs to exacerbate intermunicipal inequality. Despite evidence that it is difficult to sustain such targeting either in the U.S. Empowerment Zone program or under European Union Structural Funds (Greenbaum \& Bondonio, 2004), the weight of the evidence reviewed and presented here suggests that it is a desirable policy goal.

\section{REFERENCES}

Albornoz, F., \& Corcos, G. (2007). Regional integration, subsidy competition, and therelocation choices of MNCs. Berkeley Electronic Journal of Economic Analysis and Policy, 7, 1-27. Retrieved June 15, 2007, from http://www.bepress.com/bejeap/vol7/iss1/art1

Anderson, J. E. (1990). Tax increment financing: Municipal adoption and growth. National Tax Journal, XLIII, 155163.

Anderson, J. E., \& Wassmer, R. W. (1995). The decision to "bid for business": Municipal behavior in granting property tax abatements. Regional Science and Urban Economics 25, 739-757.

Aydin, U. (2007). From competition to cooperation: Subsidies in the United States, Canada, and the European Union. (Doctoral Dissertation, University of Washington). Dissertation Abstracts AAT 0819325.

Barros, P. P., \& Cabral, L. (2000). Competing for foreign direct investment. Review of International Economics, 8 , 360-371.

Bartik, T. (1991). Who benefits from state and local economic development policy? Kalamazoo, MI: W.E. Upjohn Institute for Employment Research Press.

Byrne, P. F. (2005). Strategic interaction and the adoption of tax increment financing. Regional Science and Urban Economics, 35, 279-303.

Dye, R. F., \& Merriman, D. F. (2000). The effects of tax increment financing on economic development. Journal of Urban Economics, 47, 306-328.

Geolytics, Inc. (2000). Census CD and maps [GIS data]. East Brunswick, NJ.

Gordon, C. (2008). Mapping decline: St. Louis and the fate of the American city. Philadelphia: University of Pennsylvania Press.

Greenbaum, R. T., \& Bondonio, D. (2004). Losing focus? A comparative evaluation of spatially targeted revitalization programs in the US and the EU. Regional Studies, 38, 319-334.

Guisinger, S. E. (1985). A comparative study of country policies. In S. E. Guisinger \& Associates (Eds.), Investment incentives and performance requirements (pp. 1-55). New York: Praeger.

Harding, T., \& Javorcik, B. S. (2007). Developing economies and international investors: Do investment promotion agencies bring them together? Unpublished paper, World Bank.

Head, C. K., Ries, J. C., \& Swenson, D. L. (1999). Attracting foreign manufacturing: Investment promotion and agglomeration. Regional Science and Urban Economics, 29, 197-218.

International City/County Management Association. (2006). The municipal year book 2006. Washington D.C.: International City/County Management Association. 
Li, Q. (2006). Democracy, autocracy, and tax incentives to foreign direct investors: A cross- national analysis. Journal of Politics, 68, 62-74.

Man, J. Y. (1999). Fiscal pressure, tax competition and the adoption of tax increment financing. Urban Studies, 36, 1151-1167.

Man, J. Y. (2001). Introduction. In C. J. Johnson \& J. Y. Man (Eds.), Tax increment financing and economic development (pp. 1-11). Albany: State Universityof New York Press.

Missouri Department of Economic Development (2004). Annual report on local TIF. Jefferson City: Department of Economic Development.

Missouri Department of Economic Development (2005). Annual report on local TIF. Jefferson City: Department of Economic Development.

Peters, A. \& Fisher, P. (2004). The failures of economic development incentives. Journal of the American Planning Association, 70, 27-37.

Reese, L. A. (2001). Yes, but...: Questioning the conventional wisdom about economic development. Economic Development Quarterly, 15, 299-312.

Reese, L. A. (2006). Not just another determinants piece: Path dependency and local tax abatements. Review of Policy Research, 23, 491-504.

Schwartz, D., Pelzman, J., \& Keren, M. (2008). The ineffectiveness of location incentive programs. Economic Development Quarterly, 22, 167-179.

State Auditor of Missouri. (1986). Review of 1985 property tax rates. Jefferson City: Office of the State Auditor of Missouri.

State Auditor of Missouri. (2005). Review of 2005 property tax rates. Jefferson City: Office of the State Auditor of Missouri.

Thomas, K. P. (2000). Competing for capital: Europe and North America in a global era. Washington: Georgetown University Press.

U. S. Census Bureau. (2008). American FactFinder 2000. Retrieved February 10, 2008, from http://www.census.gov

Wishlade, F. (2008). All's well that ends well? Recent developments in EU competition policy and regional aid control. European policy research papers, European Policies Research Centre. Glasgow: University of Strathclyde. 
TABLE 1

Variables in the Models

\begin{tabular}{|c|c|c|c|c|}
\hline $\begin{array}{l}\text { Dependent } \\
\text { Variables }\end{array}$ & Competitive & Equity & $\begin{array}{l}\text { Path } \\
\text { Dependency }\end{array}$ & Controls \\
\hline TIF Approval & $\begin{array}{l}\text { Adjacent to City } \\
\text { with TIF }\end{array}$ & Poverty Rate & $\begin{array}{l}\text { Early } \\
\text { Adopter }\end{array}$ & $\begin{array}{l}\text { Council- } \\
\text { Manager } \\
\text { Government }\end{array}$ \\
\hline Retail TIF & Miles to Nearest & \multirow[t]{2}{*}{ Unemployment Rate } & & Economic \\
\hline Approval & City with TIF & & & $\begin{array}{l}\text { Development } \\
\text { Plan }\end{array}$ \\
\hline Number of All & & \multirow{11}{*}{$\begin{array}{l}\text { Median Household } \\
\text { Income }\end{array}$} & & Uses other \\
\hline TIFs & & & & $\begin{array}{l}\text { Economic } \\
\text { Development } \\
\text { Tools }\end{array}$ \\
\hline $\begin{array}{l}\text { Number of Retail } \\
\text { TIFs }\end{array}$ & & & & $\begin{array}{l}\text { Population in } \\
\text { thousands }\end{array}$ \\
\hline Value of All TIFs & & & & Population \\
\hline$(\$)$ & & & & $\begin{array}{l}\text { Growth (1980 } \\
\text { to } 2000)\end{array}$ \\
\hline Value of Retail & & & & Percent Owner- \\
\hline TIFs $(\$)$ & & & & Occupied \\
\hline & & & & Housing \\
\hline & & & & Change in \\
\hline & & & & Total Assessed \\
\hline & & & & $\begin{array}{l}\text { Property Value } \\
(1985-2005)\end{array}$ \\
\hline
\end{tabular}


Table 2

Variables, Measurement, and Source

\begin{tabular}{|c|c|c|}
\hline Variable & Measurement & Source \\
\hline TIF Approval & Nominal & Survey Response \\
\hline Retail TIF Approval & Nominal & Survey Response \\
\hline Number of All TIFs & Interval & Survey Response \\
\hline Number of Retail TIFs & Interval & Survey Response \\
\hline Value of All TIFs & Interval & Survey Response \\
\hline Value of Retail TIFs & Interval & Survey Response \\
\hline Council-Manager Government & Nominal & ICMA \\
\hline Economic Development Plan & Nominal & Survey Response \\
\hline Uses other Economic & & Survey Response \\
\hline Development Tools & Nominal & \\
\hline Adjacent to City with TIF & Nominal & Geolytics \\
\hline Miles to Nearest City with TIF & Interval & Geolytics \\
\hline Early Adopter & Nominal & $\begin{array}{l}\text { Missouri Dept. of Economic } \\
\text { Development }\end{array}$ \\
\hline $\begin{array}{l}\text { Population in thousands } \\
\text { Population Growth (1980 to }\end{array}$ & Interval & U.S. Census \\
\hline $\begin{array}{l}\text { 2000) } \\
\text { Percent Owner-Occupied }\end{array}$ & Interval & U.S. Census \\
\hline Housing & Ratio & U.S. Census \\
\hline Poverty Rate & Ratio & U.S. Census \\
\hline Unemployment Rate & Ratio & U.S. Census \\
\hline $\begin{array}{l}\text { Change in Total Assessed } \\
\text { Property Value (1985-2005) }\end{array}$ & Ratio & State Auditor of Missouri \\
\hline
\end{tabular}


TABLE 3

Descriptive Statistics

\begin{tabular}{lrrr}
\hline Variable & Mean & \multicolumn{2}{l}{$\begin{array}{l}\text { Standard } \\
\text { Deviation }\end{array}$} \\
& N \\
\hline TIF Approval & .56 & .50 & 171 \\
Number of TIFs & 1.24 & 1.85 & 165 \\
Value of All TIFs & $12,700,000$ & $28,000,000$ & 134 \\
Retail TIF Approval & .42 & .50 & 163 \\
Number of Retail TIFs & .73 & 1.14 & 160 \\
Value of all Retail TIFs & $7,691,851$ & $19,300,000$ & 141 \\
Council-Manager Government & .43 & .50 & 185 \\
Economic Development Plan & .74 & .44 & 155 \\
Uses other Economic Development Tools & .67 & .47 & 171 \\
Early Adopter & .05 & .22 & 185 \\
Population & 12,957 & 18,587 & 185 \\
Population Growth from 1980-2000 & .55 & 2.72 & 181 \\
Percent of Owner-Occupied Housing & 67 & 12 & 185 \\
Median Household Income & 40,158 & 21,124 & 185 \\
Poverty Rate & 10.08 & 7.50 & 185 \\
Unemployment Rate & 3.31 & 1.62 & 185 \\
Average Growth Rate in Total Assessed & & & \\
Property Value (1985-2005) & 2.6 & 6.5 & 175 \\
Adjacent to City with TIF & .41 & .49 & 180 \\
Miles from City with TIF & 12 & 14 & 182 \\
\hline
\end{tabular}


The final, definitive version of this paper has been published in the Economic Development Quarterly, Vol 24 (Iss 2), 2010. SAGE Publications, Inc., All rights reserved. doi: 10.1177/0891242409358080

TABLE 4

Bivariate Correlations

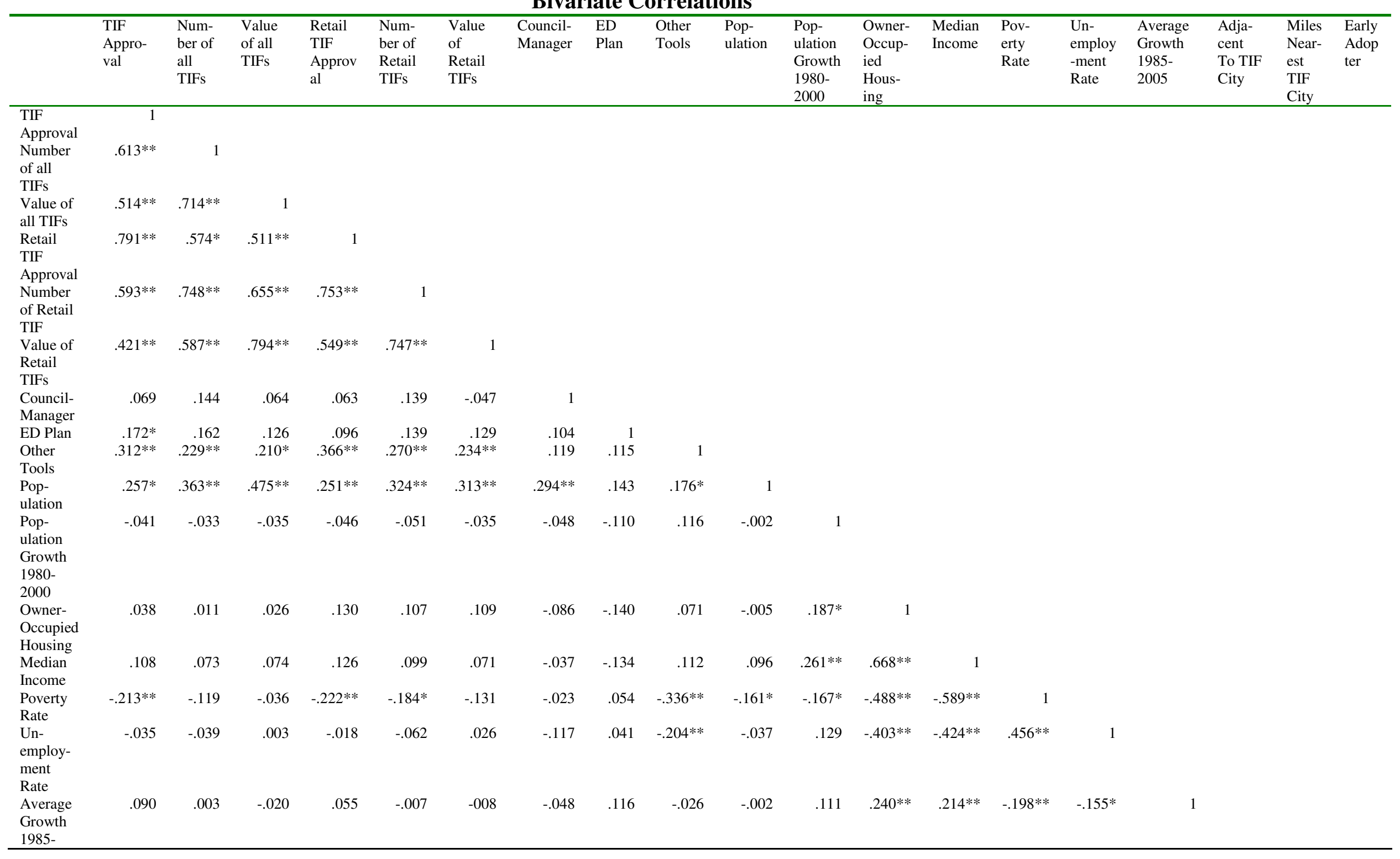


The final, definitive version of this paper has been published in the Economic Development Quarterly, Vol 24 (Iss 2), 2010. SAGE Publications, Inc., All rights reserved. doi: 10.1177/0891242409358080

\begin{tabular}{|c|c|c|c|c|c|c|c|c|c|c|c|c|c|c|c|c|c|c|c|}
\hline 2005 & & & & & & & & & & & & & & & & & & & \\
\hline $\begin{array}{l}\text { TIF } \\
\text { Appro- } \\
\text { val }\end{array}$ & $\begin{array}{l}\text { Num- } \\
\text { ber of } \\
\text { all TIFs }\end{array}$ & $\begin{array}{l}\text { Value } \\
\text { of all } \\
\text { TIFs }\end{array}$ & $\begin{array}{l}\text { Retail } \\
\text { TIF } \\
\text { Approv } \\
\text { al }\end{array}$ & $\begin{array}{l}\text { Num- } \\
\text { ber of } \\
\text { Retail } \\
\text { TIFs }\end{array}$ & $\begin{array}{l}\text { Value } \\
\text { of } \\
\text { Retail } \\
\text { TIFs }\end{array}$ & $\begin{array}{l}\text { Counci } \\
1- \\
\text { Manag } \\
\text { er }\end{array}$ & ED Plan & $\begin{array}{l}\text { Other } \\
\text { Tools }\end{array}$ & $\begin{array}{l}\text { Pop- } \\
\text { ulation }\end{array}$ & 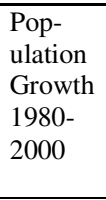 & $\begin{array}{l}\text { Owner- } \\
\text { Occup- } \\
\text { ied } \\
\text { Hous- } \\
\text { ing }\end{array}$ & $\begin{array}{l}\text { Median } \\
\text { Income }\end{array}$ & $\begin{array}{l}\text { Poverty } \\
\text { Rate }\end{array}$ & $\begin{array}{l}\text { Un- } \\
\text { employ } \\
\text {-ment } \\
\text { Rate }\end{array}$ & $\begin{array}{l}\text { Averag } \\
\mathrm{e} \\
\text { Growt } \\
\mathrm{h} \\
1985- \\
2005 \\
\end{array}$ & $\begin{array}{l}\text { Adja- } \\
\text { cent } \\
\text { To TIF } \\
\text { City }\end{array}$ & $\begin{array}{l}\text { Miles } \\
\text { Near- } \\
\text { est } \\
\text { TIF } \\
\text { City }\end{array}$ & $\begin{array}{l}\text { Early } \\
\text { Adop } \\
\text { ter }\end{array}$ & \\
\hline $\begin{array}{l}\text { Adjacent } \\
\text { To TIF } \\
\text { City }\end{array}$ & $.273 * *$ & $.287 * *$ & .121 & $.322 * *$ & $.301 * *$ & .105 & $\begin{array}{l}.069 \\
\end{array}$ & -.072 & .083 & .130 & .120 & $.346 * *$ & $.500 * *$ & $-.341 * *$ & -.096 & .118 & 1 & & \\
\hline $\begin{array}{l}\text { Miles } \\
\text { Nearest } \\
\text { TIF City }\end{array}$ & -.120 & -.124 & -.081 & $-.128^{*}$ & $-.172^{*}$ & -.054 & .092 & .057 & $-.150 *$ & -.120 & -.115 & $-.348 * *$ & $-.455^{* *}$ & $.418^{* * *}$ & .126 & -.125 & $-.739 * *$ & 1 & \\
\hline $\begin{array}{l}\text { Early } \\
\text { Adopter }\end{array}$ & $.196^{*}$ & $.431 * *$ & .087 & .093 & $.157 *$ & $.035^{*}$ & .107 & .140 & .125 & $.167^{*}$ & .058 & -.015 & .025 & -.090 & -.087 & .069 & .070 & -.079 & 1 \\
\hline
\end{tabular}


TABLE 5

Statistically Significant Binomial Logistic Regression Estimates of Economic, Competitive, and Structural Factors of Cities on TIF Approval and Retail TIF Approval with Odds Ratios (Standard Errors in Parentheses)

\begin{tabular}{|c|c|c|c|c|}
\hline $\begin{array}{l}\text { Independent } \\
\text { Variables }\end{array}$ & $\begin{array}{l}\text { TIF } \\
\text { Approval } \\
\text { Odds Ratio }\end{array}$ & $\begin{array}{l}\text { TIF } \\
\text { Approval } \\
\text { Odds Ratio }\end{array}$ & $\begin{array}{l}\text { Retail TIF } \\
\text { Approval } \\
\text { Odds Ratio }\end{array}$ & $\begin{array}{l}\text { Retail TIF } \\
\text { Approval } \\
\text { Odds Ratio }\end{array}$ \\
\hline Economic & $2.94^{+}$ & $2.56^{+}$ & & \\
\hline Development Plan & $(.48)$ & $(.46)$ & & \\
\hline Uses other Economic & $2.74 *$ & $2.49 *$ & $4.10 *$ & $3.56 *$ \\
\hline Development Tools & $(.48)$ & $(.46)$ & $(.56)$ & $(.62)$ \\
\hline $\begin{array}{l}\text { Population in } \\
\text { thousands }\end{array}$ & & $\begin{array}{r}1.04+ \\
(.02)\end{array}$ & $\begin{array}{r}1.03+ \\
(.02)\end{array}$ & $\begin{array}{r}1.05+ \\
(.02)\end{array}$ \\
\hline Poverty Rate & $\begin{array}{r}-1.09 * \\
(.04)\end{array}$ & $\begin{array}{r}-1.11^{*} \\
(.05)\end{array}$ & $\begin{array}{r}-1.11^{*} \\
(.05)\end{array}$ & $\begin{array}{r}-1.13^{*} \\
(.06)\end{array}$ \\
\hline Unemployment Rate & & $\begin{array}{r}1.47 * \\
(.18)\end{array}$ & $\begin{array}{r}1.65 * * \\
(.19)\end{array}$ & $\begin{array}{r}1.77 * * \\
(.20)\end{array}$ \\
\hline $\begin{array}{l}\text { Adjacent to City } \\
\text { with TIF }\end{array}$ & $\begin{array}{r}2.63 * \\
(.44)\end{array}$ & & $\begin{array}{r}2.99 * * \\
(.45)\end{array}$ & \\
\hline Pseudo R 2 & .21 & .19 & .26 & .23 \\
\hline LR Chi2 & $42.22 * *$ & $37.37 * *$ & $50.32 * *$ & $44.28 * *$ \\
\hline $\mathrm{N}$ & 144 & 144 & 139 & 139 \\
\hline
\end{tabular}


TABLE 6

Regression Estimates of Economic, Competitive, and Structural Factors of Cities on the Number of Total TIFs and Retail TIFs Approved (Standard Errors in Parentheses)

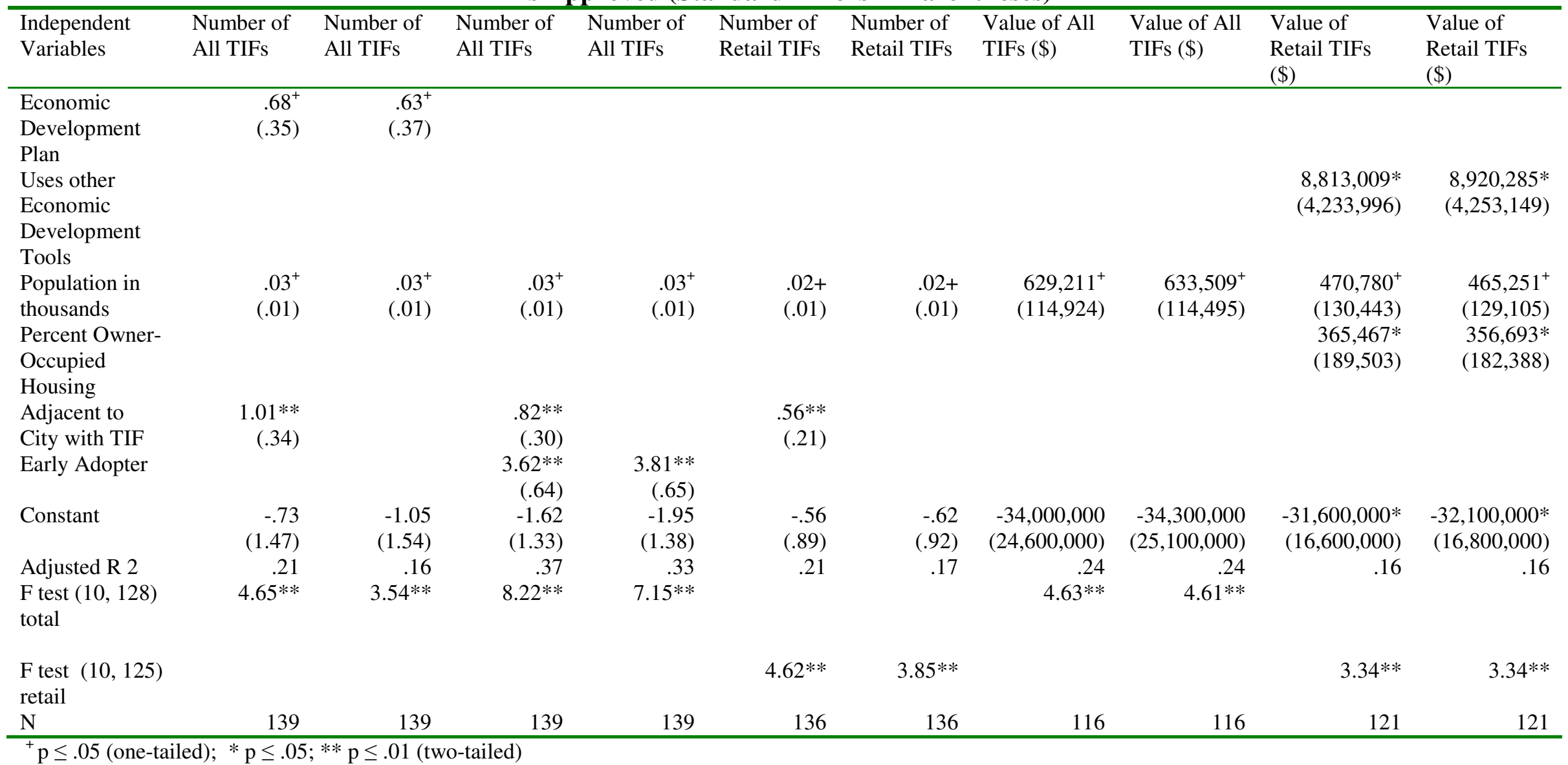




\section{APPENDIX A \\ Tax Increment Financing Survey}

As our communities change it is helpful to learn about the economic development tools used to ensure long-term growth and economic development. Your responses to this questionnaire are important for understanding the way tax increment financing is used as an economic development tool.

\section{Section A. General Questions}

The following are general questions about the way Tax Increment Financing (TIF) is used.

1. Has the city ever approved a TIF? (PLEASE CHECK ONE)

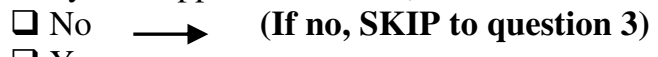

$\square$ Yes

1a. If yes, how many times?

\section{AND}

1b. What is the total value of TIFs ever awarded?

2. Has the city ever approved a TIF for a project that was primarily retail? (PLEASE CHECK ONE)

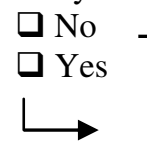

2a. If yes, how many times?

\section{AND}

2b. What is the total value of all retail TIFs ever awarded?

3. How frequently have requested TIFs been denied in the last five years? (CIRCLE A NUMBER or 00 if you Don't Know)
0
2
34
56
$\begin{array}{llll}6 & 7 & 8 & 9\end{array}$
$10+$
00

Don't Know

\section{Section B. Community Factors}

The following questions are about locus of decisions and factors that may influence the use of TIFs.

4. The primary agent/office to determine the use of TIF in your community is: (PLEASE CHECK ONE)

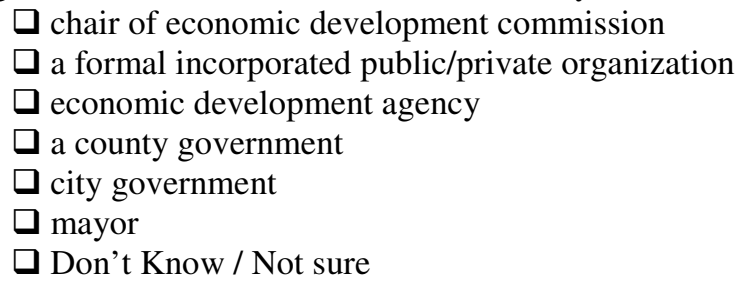

5. Was the city in competition with other cities in the nation for the projects the TIF funds supported? (PLEASE CHECK ONE)

$\square$ No
$\square$ Yes, occasionally
$\square$ Yes, always
$\square$ Don't Know / Not sure


6. Did the city compete with a nearby city for a project that used TIF funds? (PLEASE CHECK ONE)

$$
\begin{aligned}
& \square \text { No } \\
& \text { Yes, occasionally } \\
& \text { Yes, always } \\
& \square \text { Don't Know / Not sure }
\end{aligned}
$$

7. Does the city have an economic development plan for the next several years? (PLEASE CHECK ONE)

$$
\begin{aligned}
& \square \text { No } \\
& \text { Yes, informal/unwritten } \\
& \text { Yes, formal/written } \\
& \square \text { Don't Know / Not sure }
\end{aligned}
$$

8. Does the city "pool" sales tax revenues with other cities in the county? (PLEASE CHECK ONE)

$$
\begin{aligned}
& \square \text { No } \\
& \square \text { Yes } \\
& \square \text { Don't Know / Not sure }
\end{aligned}
$$

\section{Section C. Economic Development Tools Use}

Municipalities have a variety of economic development tools at their disposal. Please indicate how frequently, if at all, your community uses the following tools.

9. How many times has each of the following tools been used since 1982 ?

\section{Type}

Chapter 100 tax abatement

Chapter 353 tax abatement

Transportation development district (TDD)

Industrial development bond (IDB)

Other (Please Specify):

\section{Number of times used}

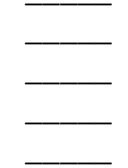

\section{Section D. Policy Considerations}

The following questions concern decision-making processes and outcome evaluations for TIF use.

10. Are there policies or guidelines governing the granting of TIFs? (PLEASE CHECK ONE)

$$
\begin{aligned}
& \square \text { No } \\
& \text { Yes, formal/written } \\
& \text { Yes, informal/unwritten } \\
& \square \text { Don't Know / Not sure }
\end{aligned}
$$

11. Does the municipality evaluate cost/benefits of TIFs prior to implementation? (PLEASE CHECK ONE)

$$
\begin{aligned}
& \square \text { No } \\
& \text { Yes, always } \\
& \square \text { Yes, occasionally } \\
& \square \text { Don't Know / Not sure }
\end{aligned}
$$

12. Is the effectiveness of TIFs evaluated on the following after implementation?

(PLEASE CHECK ALL THAT APPLY OR CHECK NONE OF THEM IF THE ANSWER IS NO)

$$
\begin{aligned}
& \square \text { Number of new jobs } \\
& \text { Increase in tax base } \\
& \text { Number of retained jobs } \\
& \text { Value of investment } \\
& \text { Other (Please Specify) } \\
& \square \text { Don't Know / Not sure }
\end{aligned}
$$


13. Are there any topics not treated in this questionnaire that you feel are important for understanding how your community uses TIF or other economic development tools? If so, please provide the information below or use additional sheets if necessary.

Thank you for your help and time in completing this survey.

\section{Endnotes}

\footnotetext{
${ }^{1}$ Note that Bartik (1991) considers moving jobs from low unemployment areas to high unemployment areas to be an increase in efficiency, as well.

${ }^{2}$ For the 57 cities that reported their value, the average TIF was $\$ 29.8$ million.

${ }^{3}$ For the 48 cities that reported their value, the average retail TIF was $\$ 22.6$ million.
} 